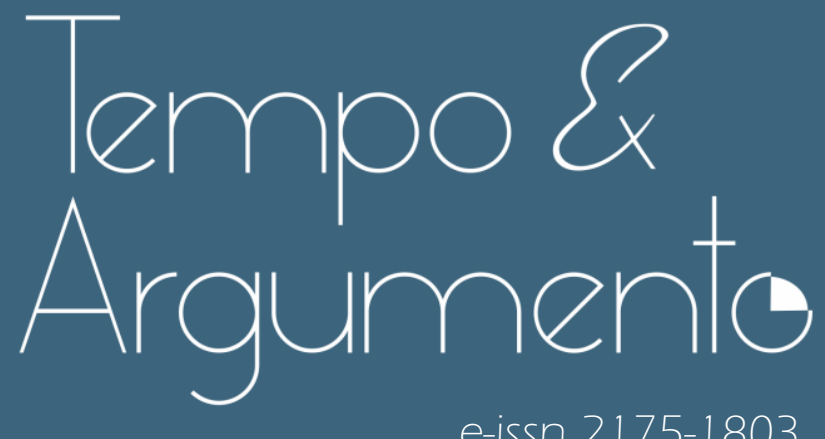

e-issn 2175-1803

\title{
Futebol em Tempos de Conflito: os grandes clubes do Rio de Janeiro e a Segunda Guerra Mundial (1942-1945)
}

- Adriano de Freixo

Doutor em História Social pela Universidade Federal do Rio de Janeiro (UFRJ).

Professor da Universidade Federal Fluminense (UFF).

Niterói, RJ - BRASIL

lattes.cnpq.br/9900636572166116

adrianofreixo@id.uff.br

(D) orcid.org/0000-0002-0361-8565

- Vagner Camilo Alves

Doutor em Ciência Política pelo Instituto Universitário de Pesquisas do Rio de Janeiro (IUPERJ). Professor da Universidade Federal Fluminense (UFF).

Niterói, RJ - BRASIL

lattes.cnpq.br/2535091837980172

vcamilo@id.uff.br

(D) orcid.org/0000-0002-4399-6835

Para citar este artigo:

FREIXO, Adriano de; ALVES, Vagner Camilo. O Futebol em Tempos de Conflito: os grandes clubes do Rio de Janeiro e a Segunda Guerra Mundial ( 1942-1945).

Tempo e Argumento, Florianópolis, v. 13, n. 32, e0 101 , jan./abr. 2021.

doi http://dx.doi.org/10.5965/2175180313322021e0101 


\title{
O Futebol em Tempos de Conflito: os grandes clubes do Rio de Janeiro e a Segunda Guerra Mundial (1942-1945)1
}

\begin{abstract}
Resumo
Em agosto de 1942, o Brasil declarou guerra à Alemanha e Itália e, no período subsequente a essa declaração, houve intensa mobilização do Estado brasileiro para articular o front externo - com a estruturação da Força Expedicionária Brasileira (FEB) - e o interno -, com a mobilização maciça dos recursos civis para o esforço de guerra. A produção historiográfica sobre o período tem priorizado a discussão da atuação do Estado nesse processo, seja através da análise da participação brasileira no conflito, seja enfatizando o seu caráter autoritário e os mecanismos repressivos por ele utilizados para mobilizar e controlar a sociedade. Estudos sobre a atuação de entidades da sociedade, que, com algum grau de autonomia e por interesses diversos, também atuaram no esforço de guerra, são relativamente escassos. Tendo como ponto de partida as relações entre Estado e sociedade durante o Estado Novo, este trabalho pretende analisar a mobilização dos principais clubes de futebol cariocas durante a Segunda Guerra Mundial, a partir de matérias publicadas pela imprensa do Rio de Janeiro e da documentação disponível no acervo dos clubes. Parte-se da hipótese de que houve, mesmo que de forma esparsa, certo grau de atuação autônoma de setores da sociedade carioca para o esforço de guerra.
\end{abstract}

Palavras-chave: História. Clubes de futebol do Rio de Janeiro. Segunda Guerra Mundial: Esforço de Guerra. Estado Novo.

\section{Football in Times of Conflict: the Major Clubs of Rio de Janeiro and the Second World War (1942-1945)}

\begin{abstract}
In August 1942, Brazil declared war on Germany and Italy. In the period following that declaration, there was intense mobilization of the Brazilian State to organize the foreign front - with the creation of the Brazilian Expeditionary Force - and the domestic one - with large-scale mobilization of civilian resources for the war effort. Historiographical production on the period has prioritized the analysis of the state's action in this process, either through its participation in the conflict or through its authoritarian character and repressive mechanisms of mobilization and control of society. The studies on the actions of the entities of society, which, with some autonomy and diverse interests, also took part in the war effort, are somewhat rare. This work intends to analyze the mobilization of the major carioca football clubs during the World War II from a perspective of the relationships between the state and society during Estado Novo. The sources for the work are reportage published by the press in Rio de Janeiro and documents available in the clubs' archives. It's assumed that there was, albeit sparingly, some autonomous action of sectors of the carioca society for the war effort.
\end{abstract}

Keywords: History. Football clubs of Rio de Janeiro. Wold War II. War Effort. Estado Novo.

\footnotetext{
A pesquisa contou com a participação de Carolina Ambinder de Carvalho, bolsista de iniciação científica CNPq/UFF do projeto "O futebol em tempos de conflito: mobilização dos clubes cariocas para o esforço de guerra (1942-1945)", desenvolvido no âmbito do Laboratório de Estudos sobre a Política Externa Brasileira - LEPEB/UFF.
} 
Tendo chegado ao Brasil nos últimos anos do século XIX, o futebol já estava profundamente integrado à cultura brasileira na década de 1930, arrebatando aficionados em todas as classes sociais. A incorporação de jogadores provenientes das classes populares ao plantel dos principais clubes e a popularização do rádio, veículo de difusão por excelência da nova paixão nacional, tiveram papel decisivo na sua democratização e massificação, acelerando o processo que vinha ocorrendo desde, pelo menos, a década anterior.

As lideranças políticas que emergiram com a Revolução de 1930², notadamente Getúlio Vargas, não tardariam a perceber o potencial político do esporte e o papel que poderia vir a desempenhar como elemento de identidade e unidade nacionais. Como assinala Luís Fernandes (2010, p. 18), a relativa ausência na formação histórica do Brasil de um elemento fundamental no processo de construção das identidades nacionais nos países centrais - a guerra - contribuiu para que, por aqui, o futebol fornecesse "um simulacro de conflito bélico para o qual era possível canalizar emoções e construir sentidos de pertencimento."

A partir dessa percepção e refletindo as tendências centralizadoras que marcaram a Era Vargas, o Estado procurou, a partir dos anos 30 do século passado, exercer maior controle sobre aquele que já era o esporte mais popular do país e sobre as práticas desportivas em geral, como, aliás, fazia em outras esferas da vida social. O debate entre os defensores do amadorismo e os do profissionalismo no futebol, por exemplo, foi acompanhado com atenção pelo presidente da República que, mesmo sem interferir diretamente na questão, deixava transparecer certa inclinação pela profissionalização do esporte, dentro

\footnotetext{
2 A partir da década de 1960, tanto no campo da História, quanto nas demais Ciências Sociais, iniciou-se grande renovação dos estudos sobre a Era Vargas e a chamada "Revolução de 30". Nesse contexto, debates sobre o caráter do movimento de 1930 e sobre sua caracterização ou não - como uma "revolução" tiveram grande centralidade, como se depreende de um dos trabalhos mais conhecidos produzidos no período: "A Revolução de 1930: historiografia e história”, de Boris Fausto, cuja primeira edição data de 1970. Por essa discussão não se inserir diretamente no escopo deste artigo, ela não será aqui tratada. Nossa opção pela utilização dos termos "Revolução de 1930" e "revolucionário" (para se referir aos que dela participaram) se dá somente por serem expressões consagradas e já incorporadas ao léxico político brasileiro. Balanços e leituras contemporâneas sobre as diferentes interpretações e debates em torno dessas questões podem ser encontrados nos trabalhos de Pansardi (2009) e Cancelli (2020).
} 
da lógica varguista de regulação do mundo do trabalho. A vitória do profissionalismo marcaria o fim de uma era, com o futebol deixando de ser um esporte de distinção, praticado segundo os valores consagrados pelos sportmen oriundos das elites econômicas e sociais (FERNANDEZ, 2010), para passar a ser o ofício de atletas profissionais, em sua maioria provenientes dos estratos sociais mais baixos e, em grande parte, negros e pardos.

O Estado Novo $^{3}$ (1937-45) acentuaria essa tendência de controle estatal sobre os esportes, controle esse que se consolidaria com a criação do Conselho Nacional de Desportos (CND), em 1941. Esse órgão vinculava todas as atividades esportivas do país ao Estado e era o responsável, dentre outras coisas, pela aprovação dos estatutos das Federações e Confederações esportivas, podendo sugerir ao MEC (Ministério da Educação e Cultura) a criação e extinção de qualquer uma delas (DRUMOND, 2008).

A percepção de Vargas sobre a paixão popular pelo futebol fez com que os estádios onde o esporte era jogado se tornassem o local por excelência das grandes manifestações cívicas e políticas. Assim, o Estádio de São Januário, de propriedade do C.R. Vasco da Gama e então a maior instalação esportiva da cidade do Rio de Janeiro, foi o palco de inúmeras comemorações oficiais. Localizado no bairro fabril de São Cristóvão e vinculado a um clube com forte apelo popular, foi lá que Getúlio anunciou a instituição do salário mínimo nacional, durante as comemorações do Primeiro de Maio de 1940, organizadas pelo Ministério do Trabalho juntamente com o DIP (Departamento de Imprensa e Propaganda). Esses grandes eventos cívicos incluíam tradicionalmente em sua programação, além de desfiles, discursos e saudações à bandeira nacional e ao presidente da República, atividades esportivas, principalmente jogos de futebol. O incentivo à prática da educação física e dos esportes foi uma política oficial do

\footnotetext{
${ }^{3}$ Uma boa análise sobre a implantação do Estado Novo, relativizando a concepção ainda bastante presente na historiografia de que o Golpe de 1937 teria sido o desfecho quase que "natural" do processo iniciado em 1930, pode ser encontrada em Pandolfi e Grynszpan (1997). Procurando compreender a dinâmica do processo que, entre 1930 e 1937, alijou diversos segmentos das elites civis e militares que haviam sido vitoriosos em 1930, os autores ressaltam sua não linearidade. Eles argumentam que os sucessivos realinhamentos e alijamentos não teriam decorrido de um plano previamente estabelecido, mas sim de necessidades que se apresentaram a cada conjuntura, com Vargas redefinindo constantemente seus esquemas de aliança, a fim de se manter à frente do processo político.
} 
regime estadonovista, que a enxergava como fundamental para a formação física e moral do cidadão e, em uma perspectiva eugênica, para o aperfeiçoamento da "raça brasileira".

A década de 1930 marcaria, também, a realização das primeiras edições do que se tornaria a mais importante e popular competição do futebol mundial, a Copa do Mundo organizada pela FIFA e, por extensão, a incorporação ao imaginário nacional daquela que seria alçada à condição de um dos símbolos máximos da nacionalidade, notadamente após a Copa de 1938: a Seleção Brasileira de Futebol. A competição realizada na França foi efetivamente um divisor de águas na história da equipe nacional. Depois de frustradas participações nas Copas de 1930 e 1934 - por conta de brigas regionais entre paulistas e cariocas e das disputas entre os adeptos do profissionalismo e os do amadorismo, que impediram que o país mandasse para os torneios a sua melhor formação -, finalmente o futebol brasileiro despontava com um time competitivo e capaz de disputar a Copa com chances de vitória.

A ótima campanha na França, que culminaria num honroso terceiro lugar, e o destaque obtido por alguns jogadores brasileiros, em especial Leônidas da Silva e Domingos da Guia, fez com que a equipe fosse saudada por milhares de pessoas em seu retorno ao Brasil (COUTO, E., 2014; DRUMOND, 2008). Tais feitos foram intensamente instrumentalizados pela propaganda varguista e, no clima de euforia em que vivia o país, chegou a se lançar a candidatura do Brasil para sediar a Copa seguinte, que deveria ocorrer em 1942 (DRUMOND, 2008). No entanto, a eclosão da Segunda Guerra Mundial - e a destruição por ela ocasionada - impediu que os torneios de 1942 e 1946 acontecessem.

A participação do Brasil nesse conflito global, a partir de 1942, também iria repercutir e afetar o futebol nacional. Seja através da convocação de atletas para a Força Expedicionária Brasileira (FEB), da atuação dos clubes no esforço de guerra ou da repressão estatal - e da subsequente "nacionalização" - a agremiações esportivas identificadas com colônias estrangeiras, o mais popular dos esportes não passaria incólume pelas conturbações externas e internas que marcariam a primeira metade da década de 1940. 
O Futebol em Tempos de Conflito: os grandes clubes do Rio de Janeiro e a

Assim, ao longo deste trabalho, procuramos analisar a participação dos quatro principais clubes de futebol da cidade do Rio de Janeiro na mobilização para o esforço de guerra, tendo como pano de fundo as disputas e transformações ocorridas no campo esportivo entre os anos 1930 e a primeira metade dos anos 1940 e, as interseções entre esse e o campo político no período.

No decorrer da pesquisa, procedemos à consulta de matérias publicadas em três importantes jornais cariocas - os diários "O Globo"4, "Correio da Manhã”5 e "Jornal dos Sports"6 - entre 1941 e 1945, buscando perceber a mobilização das agremiações esportivas para o esforço de guerra junto à opinião pública. De acordo com Capelato (1999, p. 171), naquele contexto, "o uso dos meios de comunicação tinha como objetivo legitimar o Estado Novo e conquistar o apoio dos trabalhadores à política varguista”, o que se traduziria na criação do DIP, em dezembro de 1939, que intensificaria os mecanismos de censura e controle estatal sobre os veículos jornalísticos. Nesse sentido, o papel da imprensa na

\footnotetext{
4 Fundado em 1925, "O Globo" foi um dos primeiros jornais de maior circulação a dar grande destaque ao esporte e, em especial, ao futebol. Tendo apoiado a candidatura de Armando de Salles Oliveira após o golpe de 1937, o jornal foi um dos que mais estiveram sob a mira do DIP, o que contribuiu para que a seção de esportes e o noticiário internacional passassem a ganhar maior destaque, em detrimento do noticiário político nacional. Entre 1938 e 1952, Roberto Marinho, proprietário do jornal e apaixonado torcedor do Flamengo, editaria, juntamente com Mário Filho, a revista semanal "O Globo Sportivo", que obteve grande repercussão. Durante os anos da guerra, o jornal aderiu desde o princípio à causa aliada, posicionando-se contrariamente à neutralidade inicial do Brasil. Apoiou entusiasticamente a formação da FEB e a mobilização para o esforço de guerra e, durante a campanha da Itália, editou o tabloide semanal "O Globo Expedicionário", distribuído aos combatentes.

5 Fundado em 1901, o "Correio da Manhã" rapidamente tornar-se-ia um dos mais importantes e influentes jornais cariocas. De tendências liberais, o periódico posicionou-se sistematicamente contra os governos oligárquicos da Primeira República, enfrentando, por isso, tentativas de restrição de publicação e circulação. Durante o Estado Novo, o jornal voltaria a enfrentar problemas com a censura ao tentar, em algumas ocasiões, inserir o debate político em suas páginas. Em 1945, publicaria uma controversa entrevista com José Américo de Almeida, exministro da Viação de Vargas, que teria importante papel na aglutinação das forças de oposição ao regime. Durante os anos da guerra, assumiu posição claramente pró-aliados e manteve diversos correspondentes na Europa, dentre eles Rubem Braga, Raul de Castro e Sylvia Bittencourt (RIO DE JANEIRO (Cidade), 2001). Embora os esportes não tivessem grande cobertura no jornal naquele período, matérias relacionadas à participação das agremiações esportivas no esforço de guerra ganharam certo destaque.

${ }^{6}$ Diário esportivo carioca fundado em 1931 e vendido ao jornalista Mário Filho, em 1936, que o transformaria no mais icônico jornal brasileiro dedicado aos esportes. Com excelentes relações políticas tanto com os próceres da ditadura estadonovista, incluindo Vargas, quanto com os governantes do período liberal-democrático imediatamente posterior, Mário Filho daria um tom "oficialista" ao periódico, mas sem perder a possibilidade da crítica (COUTO, A., 2011). Durante os anos do conflito mundial, o JS assumiria forte viés nacionalista, estimulando o "esforço de guerra” e publicando artigos e editoriais estabelecendo conexões entre os esportes, notadamente o futebol, a nação e a guerra que se desenrolava do outro lado do Atlântico.
} 
mobilização para o esforço de guerra e na cobertura da atuação dos clubes cariocas nesse processo poderia ser entendido somente como resultado de sua instrumentalização pelo Estado.

No entanto, jornais como "O Globo" e o "Correio da Manhã" já demonstravam apoio à causa aliada mesmo quando o governo vargas ainda mantinha posição de neutralidade e, apesar dos limites impostos pela censura, tiveram papel relevante na mobilização da opinião pública em favor da declaração de guerra à Alemanha e Itália. Assim, procuramos entender a atuação da imprensa nesse contexto numa perspectiva próxima a de Hill (2002) que, ao refletir sobre o papel da mídia na política externa - reflexão esta que pode ser estendida à análise de seu papel na política interna - definiu-a como um ator doméstico importante tanto pela influência que exerce sobre a opinião pública, quanto pela capacidade de realizar pressões indiretas - via classe política - sobre o Executivo e os formuladores políticos. Nos limites impostos por um regime autoritário, tais pressões tendem também a refletir disputas no interior do próprio governo, como as que existiam no início dos anos 1940 entre as alas "germanófila" e "americanófila” do Estado Novo.

Foram consultadas também fontes documentais presentes nos arquivos dos clubes, constituídas majoritariamente por boletins dirigidos aos associados e por relatos de caráter memorialista - alguns editados em forma de livros produzidos a posteriori. O cotejo entre essas diferentes fontes possibilitou a melhor compreensão das relações existentes entre as agremiações esportivas e o Estado Novo, no momento em que, de forma análoga ao que acontecia em outros setores, o Estado brasileiro também promovia a criação e/ou o aperfeiçoamento de mecanismos de controle sobre as entidades esportivas.

\section{O Brasil vai à Guerra}

A guerra chegou formalmente ao Brasil em agosto de 1942. Em apenas cinco dias, entre 15 e 19 daquele mês, um único submarino alemão atacou a navegação de cabotagem nacional na costa da Bahia e do Sergipe e afundou seis navios. Como resultado disso, mais de seiscentos brasileiros perderam suas vidas. Getúlio Vargas reuniu seus ministros e no dia 22 anunciou que estava 
declarado o estado de beligerância com a Alemanha e a Itália. Da ciência sobre o afundamento do vapor Baependi, o primeiro dos navios torpedeados em agosto, até o reconhecimento da guerra por parte do governo brasileiro, as ruas do Rio de Janeiro e de São Paulo foram tomadas por manifestações espontâneas de cidadãos revoltados. As massas, organizadas principalmente por entidades representativas dos estudantes, exigiam: "Queremos a Guerra!" (CYTRYNOWICZ, 2000; McCANN JR, 1995; SANDER, 2007; VIGEVANI, 1989).

Em seu discurso de sete de setembro, Vargas reconheceu o peso que a opinião pública havia exercido na formalização da beligerância brasileira, atestando:

Protestastes com indignação, solicitastes por todas as formas de expressar a vontade popular que o governo declarasse guerra aos agressores, e assim foi feito. (VARGAS, 1938-47 apud ALVES, 2002, p. 175)

A opinião pública, entretanto, não teve papel de destaque nas decisões que levaram o Brasil a ser alvo dos ataques de submarinos alemães e italianos durante todo o ano de 1942. O envolvimento brasileiro no conflito foi feito pari passu à imersão dos Estados Unidos na guerra. Os Planos Rainbow, aprovados em agosto de 1939 e elaborados com base em ordem do presidente Roosevelt para pensar a defesa norte-americana em termos hemisféricos, já previam o uso de instalações e bases em Natal e arredores pelas forças armadas estadunidenses (CONN; FARCHILD, 2000, p. 26-35). A Política da Boa Vizinhança fez com que a aproximação entre os dois países fosse realizada por meio do diálogo diplomático, com ganhos substanciais para o Brasil no processo. As demandas estadunidenses, entretanto, foram apresentadas quanto mais envolvidos na guerra eles tornavam-se.

A posterior mobilização militar nacional contou, em regra, com pouco envolvimento da população. Isso fica claro quando se examina a constituição da Força Expedicionária Brasileira (FEB), as inúmeras dificuldades para sua mobilização e sua composição onde voluntários eram exceção.

O Estado Novo eliminou do tabuleiro decisório interno o Congresso, os partidos políticos e até, em grande parte, a imprensa, controlada e censurada pelo DIP. Dentre os atores nacionais mais importantes no diálogo com as 
pressões internacionais norte-americanas destacava-se, além do próprio presidente, Oswaldo Aranha, ministro das Relações Exteriores, e o Exército, então controlado pela dupla Góes Monteiro, chefe do Estado Maior entre 1937 e 1943, e Eurico Gaspar Dutra, ministro da Guerra entre 1936 e 1945.

Da questão siderúrgica à ruptura de relações diplomáticas com o Eixo

O projeto de industrialização do Estado Novo envolvia a implantação da grande siderurgia no país. Nas palavras de Antônio Mesplé para o governo brasileiro:

Havia que fabricar o aço, fundar as "indústrias de base", que habilitariam o Brasil a engrandecer seu poderio militar, a reaparelhar seu sistema de transportes, a tornar, afinal, realidade suas imensas potencialidades econômicas. (MESPLÉ, 1989, p.33)

O Estado tinha papel fundamental nesse processo. A futura siderúrgica era pensada como uma estatal, mas sua construção era dependente de atores estrangeiros para financiamento e auxílio técnico. O apoio final norte-americano para construção da usina siderúrgica de Volta Redonda, consubstanciado nas negociações e assinatura de um acordo nos Estados Unidos, em setembro de 1940, foi notável vitória da política externa varguista.

Após negociações infrutíferas com a U. S. Steel Co., em 1939-40, que desistiu de participar da empreitada em virtude de vários fatores ${ }^{7}$, a questão ganhou destaque nas relações Brasil-Estados Unidos devido ao desdobramento da guerra na Europa. Já em fins de maio de 1940, com a Blitzkrieg em plena e vitoriosa operação no front ocidental, o Departamento de Estado norteamericano sinalizou, pela primeira vez, sua disposição em resolver a questão a contento do governo brasileiro (CORSI, 2000, p. 157).

Explorando a oportunidade, Vargas (1938- 47 apud ALVES, 2002, p. 104) proferiu famoso discurso no encouraçado Minas Geraes, em 11 de junho, no qual saudou "as nações fortes que se impõem pela organização baseada no sentimento de Pátria, sustentando-se pela convicção da própria superioridade."

\footnotetext{
7 Nas palavras de Francisco Corsi (2000, p. 151), eles eram "desde problemas de ordem financeira até o receio quanto às intenções nacionalizantes do governo Vargas, passando pela questão do controle acionário da empresa."
} 
Ocorrida exatamente um dia após a aproveitadora declaração de guerra italiana à França e Reino Unido, a fala do presidente era um aviso. Alertas mais claros sucederem-se, com encontros reservados de Vargas com o embaixador alemão no Rio de Janeiro para discutir eventual auxílio daquele país ao projeto siderúrgico nacional. Tais sinais foram entendidos pelo par norte-americano, conforme atesta mensagem para a Secretaria de Estado de Jefferson Caffery, embaixador estadunidense no Brasil:

se os alemães fornecerem os armamentos e financiarem a siderurgia, ou se eles fizerem apenas um dos dois, seria inútil para nós alimentar qualquer esperança de que poderemos manter nossa posição no Brasil. É igualmente inútil falar sobre nossos planos econômicos e financeiros em grande ou pequena escala se não resolvermos esses dois assuntos ... Chegou o tempo em que devemos decidir se manter o Brasil fora da órbita alemã justifica que se corram estes riscos, e se eles são de fato riscos. (GAMBINI, 1977, p. 133-134 apud ALVES, 2002, p. 105)

A diplomacia da equidistância pragmática, termo cunhado por Gerson Moura para designar a política externa comercial brasileira da segunda metade da década de 1930, chegara ao fim (MOURA, 1980). Com o início da guerra e, mais especificamente, com a radical mudança do cenário estratégico devido à vitória alemã no front ocidental, em maio/junho de 1940, a questão, como muito bem pergunta Carlos Duarte, é se houve, a partir de então, diplomacia pendular ou hegemonia americana? A resposta é que o pêndulo, ou o jogo diplomático de Vargas com alemães e norte-americanos, restringiu-se basicamente à solução da questão siderúrgica (DUARTE, 1989, p. 24-25). O ditador brasileiro soube barganhar no momento certo. A solução do problema, entretanto, levava inexoravelmente o Brasil a uma relação mais próxima com os Estados Unidos, que se preparava de maneira cada vez mais ostensiva para enfrentar militarmente seus adversários no plano internacional. Para fazer isso, a utilização de bases em território brasileiro era fundamental. Tal aspecto ganhará relevo na relação entre os dois países.

A importância do nordeste brasileiro para a comunicação aérea entre o novo e o velho mundo já era reconhecida antes mesmo da confecção dos Planos Rainbow. Em artigo na prestigiosa revista Foreign Affairs, no início de 1938, especialista em transporte aéreo, indicava Natal, há aproximadamente 3.000 
quilômetros de distância da África Ocidental, como uma das chaves para a comunicação área no Atlântico Sul (WARNER, 1938 apud ALVES, 2002, p. 91-94). Com a aproximação diplomática entre Estados Unidos e Brasil, pressões por parte dos norte-americanos visando resolver tal pendência têm início já no princípio de 1941. A defesa hemisférica naquele momento implicava no fim da operação de linhas aéreas do Eixo no Brasil, na construção de bases no nordeste brasileiro e no acantonamento de tropas estadunidenses para resguardá-las. Salvo o último aspecto, os demais pontos foram resolvidos antes de Pearl Harbour (McCANN JR., 1995, p. 175).

O Programa de Desenvolvimento de Aeroportos (ADP, na sigla em inglês), formulado em fins de 1940, tinha o Brasil como um de seus principais objetos. No início de 1941 os norte-americanos, por intermédio da PANAIR, subsidiária nacional da Pan-American, conseguiram permissão verbal de Vargas para darem início à construção dos aeroportos. O decreto autorizando tais obras só foi assinado em junho, mas os trabalhos já tinham começado e, em maio, ocorreu o primeiro voo de aeronaves militares estadunidenses em direção aos fronts do velho mundo. O que seria conhecido como "Trampolim para a Vitória", importante elo da cadeia logística de comunicação área norte-americana durante toda a Segunda Guerra Mundial, iniciou suas atividades seis meses antes da entrada formal dos Estados Unidos na guerra (McCANN JR., 1995, p. 184-192).

A interação entre as pressões da potência norte-americana e o pequeno grupo decisor nacional, que respondia pela política externa brasileira de forma praticamente isolada da sociedade, levava o Brasil mais próximo à guerra. A formalização do conflito dos Estados Unidos com o Eixo, em dezembro de 1941, fez o Departamento de Estado convocar uma reunião dos ministros das relações exteriores de todas as repúblicas americanas para tomarem decisão conjunta em face da nova configuração internacional.

A diplomacia estadunidense queria solidariedade de seus vizinhos latinoamericanos. Isso, na visão de Washington, importava na ruptura de relações diplomáticas, com todo o Eixo, pelos países que ainda não o tinham feito. Incluso nesta lista figurava o Brasil. Não sem motivos, a 3a Reunião de Chanceleres do hemisfério foi agendada para acontecer em janeiro de 1942, no Rio de Janeiro. vargas deixou para efetuar a ruptura no último dia do encontro, explorando as 
O Futebol em Tempos de Conflito: os grandes clubes do Rio de Janeiro e a

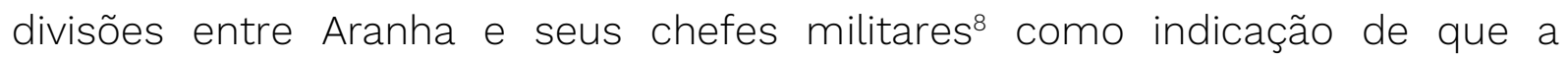
aproximação com os Estados Unidos ainda não lograra benefícios suficientes, em termos econômicos e militares. O rompimento de relações diplomáticas com o Eixo, entretanto, colocava o Brasil em um caminho sem volta.

\section{Missão Souza Costa, declaração de guerra, mobilização e a FEB}

Souza Costa, ministro da Fazenda, foi enviado a Washington quase imediatamente depois de finalizada a conferência. Viajou para cobrar a contraprestação norte-americana à decisão de Vargas em unir-se aos Estados Unidos na grande guerra que se iniciava, do ponto de vista do novo mundo.

Os acordos de Washington, como são conhecidos os instrumentos negociados pelo ministro, consolidaram a inserção brasileira no bloco de poder norte-americano, processo iniciado três anos antes, quando Oswaldo Aranha foi à capital norte-americana a convite do presidente Roosevelt, para discutir as relações bilaterais dos dois países (ALVES, 2007, p. 73). Além de destinar recursos e tecnologia para a contínua industrialização nacional, os acordos tornaram o mercado norte-americano praticamente o único destino de uma grande quantidade de matérias-primas brasileiras, inclusive estratégicas. ${ }^{9}$ Mais importante ainda, entretanto, foram os acordos militares negociados por Souza Costa. Créditos no valor de US\$200 milhões, vinculados à Lei de Empréstimos e Arrendamentos, foram disponibilizados para aquisição de equipamento bélico nos Estados Unidos. ${ }^{10}$ A aproximação entre os estamentos militares redundou na criação de Comissões Militares Conjuntas, no Rio de Janeiro e em Washington, em maio de 1942, levando à diminuição das restrições castrenses brasileiras ao aliado estadunidense. Era, na verdade, o início da americanização do Exército brasileiro, que se estenderia por parte considerável dos anos pós Segunda Guerra Mundial.

\footnotetext{
8 Dutra e Góes Monteiro, contrários, afirmavam que tal passo levaria o país inevitavelmente à guerra, e que "as Forças Armadas não se achavam suficientemente equipadas para assegurar a defesa de nosso território" (McCANN JR., 1995, p. 205). Já Aranha, advogado de uma aliança estreita com os Estados Unidos, ameaçou renunciar de público, ao final da conferência, caso o país não rompesse suas relações com o Eixo. (McCANN JR., 1995, p. 207).

9 Isso pode ser referendado pela informação de que 60\% das exportações nacionais nos anos de 1942 e 1943 correspondiam a negócios relacionados aos acordos (CORSI, 2000, p. 218).

10 Ao fim, o total de transações chegou a US\$ 322 milhões, o que correspondia a 20\% das importações brasileiras entre 1941 e 1945 (CORSI, 2000, p. 199). Tal aporte tornou o Brasil a maior potência militar sul-americana de então.
} 
A consagração da aliança Brasil-Estados Unidos tornou o país, naturalmente, alvo da guerra que agora contrapunha o Eixo aos Estados Unidos. O significado disso, no ano de 1942, era ter navios elencados como eventuais presas dos U-Boats operando no Oceano Atlântico. A guerra submarina, empreendida no litoral americano a partir de janeiro de 1942, atingiu, assim, os navios mercantes nacionais cruzando as costas norte-americanas e caribenhas. No início de agosto, um total de treze embarcações mercantes já havia sido posta a pique por submarinos do Eixo (SANDER, 2007). Em agosto, ocorreram os ataques à navegação de cabotagem no litoral nordestino.11

A mortandade resultante desses últimos ataques levou às grandes manifestações populares em prol da formalização da guerra. O governo, que deliberava palacianamente sobre aspectos da política externa nacional que aproximavam o país cada vez mais do conflito, teve de lidar momentaneamente com um novo ator. A declaração de guerra brasileira foi fruto, também, de pressões populares. As Forças Armadas, entretanto, como externaram seus chefes inúmeras vezes, não estavam preparadas para participar de uma guerra daquele tipo.

A mobilização foi em grande medida improvisada e não contou com participação popular relevante, a despeito do papel que as manifestações tiveram no reconhecimento da beligerância brasileira. O improviso no preparo para a guerra pode ser ilustrado pelo plano de mobilização, apresentado pelo general Góes Monteiro ao secretário da Marinha norte-americana Frank Knox, em outubro de 1942, feito em menos de 24 horas. Nele, previa-se potencial constituição de um exército com milhões de soldados, algo que a futura mobilização da FEB mostraria ser irreal (ALVES, 2007, p. 97).

A Força Expedicionária foi um projeto engendrado pela cúpula do Estado Novo, e respondia aos interesses de cada um dos grupos que compunham o governo. Vargas foi o articulador mor da empreitada. Em meados de 1942, o presidente já iniciara o processo de descompressão da ditadura estadonovista,

\footnotetext{
11 Em maio, a marinha alemã foi autorizada a atacar qualquer navio mercante sul-americano armado, com exceção dos argentinos e chilenos. Em julho, navios brasileiros de qualquer tipo passaram a ser arrolados como potenciais alvos. Finalmente, em agosto, o litoral brasileiro foi liberado para operações de U-Boats (RAHMEIER, 2009, p. 338-342).
} 
ainda que de forma lenta e gradativa. ${ }^{12}$ Nos anos seguintes, Getúlio reconfigurará sua persona política, de ditador para líder populista, utilizando para isso a FEB e as leis trabalhistas. Seus interesses internos conjuminavam-se, naquele momento, também com sua crença no pragmatismo da aliança com os Estados Unidos como forma de ajuda ao projeto de modernização, industrialização e maior acesso a decisões internacionais pelo Brasil.

O presidente anunciou o projeto expedicionário pela primeira vez em discurso proferido no último dia do ano de 1942. A plateia era composta quase exclusivamente de militares (ALVES, 2007, p. 105). No encontro de Vargas com Roosevelt em Natal, menos de um mês depois, o presidente estadunidense deu seu aval à iniciativa. Este foi o momento da decisão, visto a dependência que o projeto tinha do auxílio norte-americano para sua consagração. Destaque-se que se tratava de demanda brasileira e não o contrário.

A propósito, deve-se frisar o que os militares brasileiros buscavam com a iniciativa: mais armas. Eles pensavam a participação direta na guerra como forma de potencializar a recepção de equipamentos militares via Lei de Empréstimos e Arrendamentos. A ciência de que assim deveriam proceder para alcançar tal objetivo provinha dos próprios militares estadunidenses parceiros nas comissões de defesa criadas em maio de 1942 (CARVALHO, 1952, p. 270). ${ }^{13}$ A FEB foi pensada em tais comissões como um Corpo Expedicionário composto por três divisões de infantaria e unidades auxiliares menores. Em agosto de 1943, o general Dutra assinou portaria criando oficialmente a primeira divisão expedicionária que, ao fim, seria a única.

A mobilização militar encontrou diversos entraves e a falta de engajamento popular com a empreitada expedicionária não pode ser diminuída. São ilustrativos os dados fornecidos pelo ministro da Guerra a respeito:

\footnotetext{
12 Após a primeira manifestação popular pró-Aliados, feita no dia quatro de julho, data nacional norte-americana, uma crise estourou na cúpula governamental. Vargas aproveitou-se disso para livrar-se de seus colaboradores mais simpáticos ao Eixo, como Filinto Müller, chefe da polícia do Distrito Federal, e Francisco Campos, ministro da Justiça, substituindo-os por figuras menos avessas à causa Aliada (ALVES, 2007, p. 108)

${ }^{13}$ A resolução que previa o aparelhamento de unidades nacionais no Norte e Nordeste do país, de número 14, tinha redação atestando a possibilidade de uso de tais forças em outras operações e em colaboração com forças norte-americanas, consoante decisão do governo brasileiro. Ela foi aprovada em 20 de janeiro de 1943 (OLIVEIRA, 2015, p. 57-59).
} 
[...] em primeiro lugar, apelou-se para o voluntariado, aberto desde o mês de julho de 1943, em todas as regiões militares, para jovens entre 21 e 26 anos de idade.

Em torno desse recrutamento foi feita intensa campanha, através do rádio, dos jornais e dos cartazes, mas não obstante toda essa campanha e apesar da oportunidade que se proporcionava acerca de 2.400.000 jovens daquela idade para apresentação espontânea, verificou-se que apenas 2.750 apareceram, e destes somente 1.357 foram julgados aptos ao serviço militar.

À vista disso, recorreu-se a convocação obrigatória de algumas classes de reservistas, com as mesmas dificuldades [...]. (LEITE; NOVELLI JR., 1983, p. 558 apud ALVES, 2007, p. 91-92, grifos do autor)

A constituição da divisão expedicionária foi baseada, conforme destaca Dutra, na convocação daqueles que haviam prestado o serviço militar obrigatório. O exército mobilizado aumentou seu efetivo de 95 mil combatentes para 165 mil. Para isso, valeu-se basicamente da convocação dos reservistas de 1941 e 1942 e da extensão no serviço daqueles inscritos em 1943 (FERRAZ, 2012, p. 53). Referendando a informação sobre o pouco interesse dos jovens em lutar, Lima Brayner, chefe do Estado Maior da FEB, atesta em suas memórias que mesmo às vésperas do embarque do primeiro escalão da FEB para o front, soldados esforçavam-se e alguns conseguiam ser liberados da força (BRAYNER, 1968 apud ALVES, 2007, p. 92).

A ditadura estadonovista, a despeito do processo de descompressão, reprimia ainda com força manifestações sociais contrárias aos interesses do governo. Os estudantes e suas entidades representativas, fundamentais nas passeatas de julho e agosto de 1942, não encamparam a empreitada expedicionária. Muitos viam a constituição da Força como manobra da ditadura e clamavam que melhor uso na luta contra o autoritarismo se faria se os expedicionários fossem empregados contra o próprio Estado Novo. ${ }^{14}$

A FEB terminou por constituir-se somente de uma única divisão, composta por pouco mais de 25.000 homens. ${ }^{15}$ Compuseram a força, em sua maioria,

\footnotetext{
${ }^{14}$ Em fins de 1943, estudantes da Faculdade de Direito de São Paulo, uma das mais destacadas na oposição ao Estado Novo, bradavam publicamente o seguinte verso: Oh Valente legionário/Do Corpo Expedicionário/Por que vais lutar a esmo/se a luta cruenta e fria/É pela democracia/Vamos travá-la aqui mesmo (DULLES, 1984 apud ALVES, 2007, nota 104, p. 236). O governo, para desmobilizar o citado movimento estudantil, acabou convocando alguns de seus líderes para a guerra (FERRAZ, 2012, p. 61).

${ }^{15}$ Vargas, em fins de 1944, decidiu suspender a formação de novas divisões febianas, pondo termo ao projeto de constituição do Corpo Expedicionário (ALVES, 2007, p. 119).
} 
camponeses e trabalhadores, da indústria e do comércio, que não apresentavam grande motivação ideológica para ali estar. ${ }^{16}$ Faltava-lhes, acima de tudo, padrinhos, institucionais ou pessoais, que os livrassem da convocação. Francisco Ferraz considera que a mobilização da força foi marcada, de um lado, pelo “jeitinho" para livrar-se da guerra e, de outro, pela convocação e engajamento como punição, dois aspectos que a distanciavam do moderno recrutamento militar (FERRAZ, 2013). Boris Schnaiderman, ele próprio um motivado febiano, exceção à regra, em relato literário semibiográfico, diversas vezes atesta a falta de interesse de seus companheiros de caserna acerca das razões da luta que eles travavam e suas visões pessimistas sobre os motivos que os levaram à guerra. João Afonso, alter ego do escritor, em passagem ao final do livro referenda isso:

Estes homens que não queriam ir para a guerra, que não acreditavam no que se dizia das atrocidades do nazismo, que se julgavam vendidos por dólares, lutaram sobre a neve contra um inimigo feroz e eficiente. Lutaram com obstinação, praticaram com a maior naturalidade atos de heroísmo, sem exaltação, sem qualquer entusiasmo, sem compreender por que e para que o faziam. (SCHNAIDERMAN, 1995, p. 219)

Roney Cytrynowicz, examinando o dia a dia da cidade de São Paulo durante a guerra, atesta que a memória da população que viveu aqueles tempos gira, mormente, em torno da escassez de produtos e de eventuais exercícios de black out. A exceção foram os nacionais do Eixo e seus descendentes, que se recordam desses tempos como momentos de privações e perseguição (CYTRYNOWICZ, 2000). Memórias de outros personagens que viveram os tempos de guerra salientam o pouco envolvimento popular com o conflito, a despeito da propaganda feita pelo regime. ${ }^{17}$

As grandes manifestações estudantis de julho e agosto de 1942 pareceram, em um primeiro momento, o início de uma virada radical nos rumos da política

\footnotetext{
${ }^{16}$ De acordo com o médico e capitão Mirandolino Caldas, lotado no Posto Avançado de NeuroPsiquiatria da FEB, 50\% dos soldados e convocados por ele examinados em 1943 não sabiam as razões por que o Brasil tomava parte da 2a Guerra Mundial (CALDAS, 1950, p. 19-20 apud FERREIRA JÚNIOR, 2007, p. 17).

${ }^{17}$ Carlos Drummond de Andrade, chefe de gabinete de Gustavo Capanema, ministro da Educação, lembra, em diário, do meticuloso preparo do comício em comemoração aos dois anos da declaração de guerra, em agosto de 1944, onde havia tudo menos vibração. A grande faixa erguida próxima ao Teatro Municipal, com os dizeres "Ordem e Disciplina", celebrava, na visão do escritor, "o aniversário de uma guerra sui generis, do fascismo interno contra o fascismo externo" (ANDRADE, 1985, p. 15 apud FERRAZ, 2012, p. 51).
} 
nacional. Não foi o que aconteceu. Seu impacto no processo decisório é notório, a despeito de discordâncias acadêmicas. ${ }^{18}$ Retrospectivamente, entretanto, tratase de evento único. As decisões que envolveram o Brasil na guerra até ali foram tomadas por um círculo decisório restrito. O mesmo pode-se dizer do que foi decidido depois, especialmente acerca da meta de criar e preparar uma força expedicionária para combater no além-mar. Como resultante disso, a população como um todo parece não ter encampado, com vigor e ímpeto, o projeto FEB e a mobilização para lutar diretamente contra o nazi-fascismo na Europa. A contradição inerente de um regime autoritário, com laivos fascistas, mobilizar soldados para lutar pela liberdade e democracia alhures teve sua cota de responsabilidade no alheamento que, de forma geral, a opinião pública demonstrou para com a mobilização militar e o esforço expedicionário.

\section{Os clubes de futebol cariocas e o "esforço de guerra"}

Em 15 de abril de 1942, o "Jornal dos Sports" noticiava que o Clube de Regatas Vasco da Gama realizaria uma "conferência cívico-cultural", no Palácio Tiradentes, com o tema "Jovens do Brasil, sentido!", visando estimular a juventude a se voluntariar para lutar pelo país (A PRIMEIRA..., 1942, p. 6). A mesma edição destacava que o popular clube carioca mantinha em sua sede, no bairro de São Cristóvão, "a maior e mais bem organizada Escola de Instrução Militar, a de no 307, que fornece anualmente às reservas do Exército Nacional, quase um milhar de reservistas". Nos meses seguintes, matérias similares sobre o engajamento das agremiações esportivas cariocas no esforço de guerra se tornariam constantes não só nas páginas desse diário esportivo, mas também nas dos demais veículos de imprensa do Rio de Janeiro.

A entrada formal do Brasil no conflito, em agosto de 1942, intensificaria a mobilização do Estado brasileiro para articular o front externo - através da já mencionada estruturação da Força Expedicionária Brasileira (FEB) - e o interno, ou seja, a mobilização maciça dos recursos civis para os esforços de guerra

\footnotetext{
${ }^{18}$ As manifestações populares também podem ser entendidas como fruto de manipulação do governo para arregimentar apoio popular à sua decisão de formalizar a guerra. Elas, em consequência, constituíam amparo ao regime político, esvaziando seu caráter antidemocrático (CYTRYNOWICZ, 2000, p. 332).
} 
(SEITENFUS, 2000). Foi nesse último que os principais clubes esportivos cariocas buscaram se engajar com certo protagonismo, ao conseguirem adesão relativamente expressiva de seus associados e torcedores, apesar do distanciamento que a maior parte da sociedade manteve em relação à participação brasileira na guerra.

No entanto, a produção historiográfica sobre o período tem priorizado a discussão da atuação do Estado nesse processo, seja através da análise da participação brasileira no conflito, no âmbito dos estudos militares e nos de política externa, seja enfatizando o seu caráter autoritário e os mecanismos repressivos por ele utilizados para mobilizar e controlar a sociedade (CYTRYNOWICZ, 2000). Com isso, os estudos sobre a atuação de entidades da sociedade e associações não estatais que, por interesses vários e com certa autonomia, também se engajaram no esforço de guerra, ainda são relativamente escassos. Nesse sentido, há que se registrar os recentes trabalhos sobre a atuação dos trabalhadores e suas organizações de classe nesse momento, bem como sobre os impactos do conflito global no mundo do trabalho (FORTES; RIBEIRO, 2019).

No âmbito da História do Esporte não é muito diferente: os poucos trabalhos que abordam direta ou indiretamente a temática têm como foco principal, em regra, a repressão estatal sobre clubes identificados com colônias estrangeiras, vistas como ameaças pela ditadura estadonovista, em especial aquelas de nacionais de países do Eixo (AGOSTINO, 2002; SALUN, 2007), inserindo-se assim nos estudos mais amplos sobre a nacionalização e a integração forçada de comunidades estrangeiras levadas a cabo pelo governo Vargas. Destaca-se, nesse contexto, a resolução do Conselho Nacional de Desportos (CND) que proibia que em encontros esportivos houvesse quaisquer tipos de manifestações alusivas a outras nacionalidades (AGOSTINO, 2002, p. 146), atingindo clubes como os "Palestra Itália" de SP e MG (Sociedade Esportiva Palmeiras e Cruzeiro Esporte Clube, respectivamente) e, de forma menos óbvia, o Sport Club Corinthians Paulista (SALUN, 2007).

Porém, esse processo não afetaria os grandes clubes do então Distrito Federal que, já nos anos 1930, estavam sendo alçados à condição de agremiações 
de alcance nacional, principalmente pela rápida popularização do rádio e pela expansão da imprensa esportiva especializada. Tendo somente um dos grandes clubes identificação com uma colônia estrangeira - embora com especificidades óbvias que a diferiam das demais -, seria justamente esse, o C.R. Vasco da Gama, um dos que teriam atuação mais destacada na mobilização para o esforço de guerra, como discutiremos a seguir.

\section{a) Clube de Regatas Vasco da Gama}

Os anos 30 do século passado marcaram a retomada de relações mais intensas entre Brasil-Portugal. Os interesses e simpatias mútuas entre os regimes instaurados dos dois lados do Atlântico (convém lembrar que o Estado Novo brasileiro toma emprestada a denominação de seu congênere português) interromperam o "afastamento preocupante entre os dois países de língua portuguesa” (MENESES, 2011, p. 24). Nesse contexto, criaram-se condições para uma intensa aproximação - e colaboração - entre a colônia portuguesa no Brasil, de orientação majoritariamente conservadora, e o governo de Getúlio Vargas, indo muito além da retórica da herança histórica e cultural comum ou do sentimento da existência de uma "relação especial" entre os dois países.

Assim, nem mesmo a forte atuação nacionalista do governo brasileiro no período era vista como empecilho para tal aproximação, como assinalava, em editorial, a "Voz de Portugal", importante periódico da comunidade lusitana do Rio de Janeiro:

O nacionalismo do Brasil em nada contenda com o nacionalismo de Portugal, o nacionalismo de Portugal em nada afeta 0 nacionalismo do Brasil. Existe, porém, um forte ponto de contato: é a oportunidade desse sentimento nas duas pátrias. É com esse nacionalismo que, continuando a manter integralmente nossas relações com os povos amigos, nós, brasileiros e portugueses nos defenderemos da investida desferida de Moscou sobre o mundo. Não aceitamos, nem admitimos, intromissões [...]. (EDITORIAL, 30 jul. 1936, p.2 apud PAULO, 2000, p.218)

Desde sua ascensão à chefia do governo, Getúlio Vargas - e também diversos outros integrantes de seu círculo político - seria figura constante em eventos e cerimônias organizados pela colônia portuguesa, notadamente a do Rio de Janeiro, e a instauração do Estado Novo no Brasil intensificaria ainda mais 
essa proximidade. Em 1939, por exemplo, o chefe de Estado brasileiro seria homenageado pela Federação das Associações Portuguesas do Brasil, em cerimônia realizada no Real Gabinete Português de Leitura, pelas "facilidades especiais" concedidas aos imigrantes portugueses, recebendo o presidente, nessa ocasião, "um retrato seu, encomendado pela Federação e pintado por Eduardo Malta, o mesmo que pintara o quadro retratando Salazar" (PAULO, 2000, p. 219).

A intensificação da repressão e da vigilância sobre as colônias estrangeiras que se intensificaria após o rompimento de relações diplomáticas com as potências do Eixo não atingiria os imigrantes portugueses. Ao contrário: em vista da solicitação de que Portugal passasse a representar os interesses brasileiros nos países onde as embaixadas foram encerradas, a colônia portuguesa seria vista pelo regime varguista "como uma possível aliada e defensora da posição brasileira em relação às autoridades de Lisboa" (PAULO, 2000, p. 225), que viam com preocupação a crescente aproximação entre Brasil e EUA e o iminente envolvimento brasileiro no conflito.

Dividida inicialmente entre aqueles que defendiam o alinhamento integral com a posição de neutralidade do governo português e os que pregavam o apoio à causa aliada - dentre esses inúmeros integrantes da oposição portuguesa -, com o desenrolar dos acontecimentos, a colônia acabaria por se alinhar totalmente à posição brasileira, imediatamente após a decretação do "estado de beligerância" com a Alemanha e a Itália, mesmo a contragosto da ditadura salazarista. A partir daí, a comunidade lusa, em sintonia com os apelos das autoridades brasileiras, logo se engajaria no esforço de guerra: de imediato, a Real e Benemérita Sociedade Portuguesa Caixa de Socorros D. Pedro V arrecada 10.000,00 cruzeiros para uma subscrição aberta pela esposa do ministro das Relações Exteriores, Oswaldo Aranha, em prol das vítimas dos torpedeamentos de navios brasileiros (PAULO, 2000, p. 232).

Indubitavelmente, as relações estreitas entre o governo Vargas e a colônia portuguesa, e o engajamento desta no esforço de guerra, são fatores importantes para a compreensão da atuação que o C.R. Vasco da Gama teria nesse processo. É de se notar, por exemplo, que durante o processo de nacionalização das 
agremiações esportivas pelo CND, quando se estabelece que elas só poderiam ser presididas por brasileiros natos ou naturalizados, abre-se uma exceção para "os portugueses que tivessem se destacado nos meios desportivos" (DRUMOND, 2006, p. 130). No entanto, outras questões também devem ser consideradas, até porque a aproximação entre o Presidente da República e o clube de São Januário havia se iniciado ainda na década anterior, desde antes do golpe que implantou a ditadura estadonovista.

Percebendo a crescente importância do futebol e dos espaços simbólicos a ele relacionados, Vargas transformaria o estádio do clube - o maior do Rio de Janeiro e do Brasil até 1940, quando o Pacaembu foi inaugurado - no palco, por excelência, das manifestações públicas de seu governo, o que se intensificaria durante os anos do Estado Novo (COUTO, E., 2014). Situado em uma região fabril, a "Manchester brasileira", e com grande concentração de operários, as grandes cerimônias públicas em São Januário - o "Estádio dos Trabalhadores" como ficaria conhecido (COUTO, E., 2014, p. 45) -, estão diretamente relacionadas à construção da imagem de Getúlio como liderança popular e trabalhista.

É necessário ressaltar também, nesse contexto, a história e a trajetória do C.R. Vasco da Gama. Fundado por imigrantes portugueses - em sua maioria, empregados do comércio -, o clube teve papel central e pioneiro na deselitização do futebol brasileiro (e, posteriormente, no processo de implantação do profissionalismo no esporte), incorporando atletas negros e de origem operária e se impondo contra os aristocráticos clubes da elite carioca (SANTOS, 2010). Com sua sede localizada na zona norte da cidade e com torcedores concentrados, principalmente, nessa região e nos bairros suburbanos, a identidade clubística que então se consolidava no clube de São Cristóvão ia perfeitamente ao encontro do ideário varguista.

Assim, por inúmeras vezes, o gremista Getúlio Vargas expressaria publicamente sua simpatia pela agremiação carioca e fortes vínculos se estabeleceram entre o chefe de Estado e os dirigentes vascaínos. Convém ressaltar que entre 1942 e 1944, o Vasco da Gama foi presidido pelo empresário Cyro Aranha, revolucionário de primeira hora em 1930 e irmão de Oswaldo Aranha e de Luiz Aranha, dirigente do Botafogo e presidente da Confederação Brasileira 
de Desportos (CBD) ${ }^{19}$ entre 1936 e 1943, tendo chegado ao comando dessa entidade com claro apoio do governo federal (SARMENTO, 2006). Tais conexões estreitavam ainda mais os laços entre o clube e o círculo governista.

Todas essas questões explicam o entusiasmado engajamento do clube, desde o início, no esforço de guerra. Já nos primeiros meses de 1942, o CRVG teria papel destacado na campanha do pró-avião "Pax". Liderada pela CBD, no espírito da Campanha Nacional de Aviação, ela visava angariar recursos para a doação de uma aeronave à recém-criada Força Aérea Brasileira e envolveu todas as entidades e agremiações esportivas do país. Em maio daquele ano, a entidade já havia conseguido arrecadar "mais de 18 contos para o Pax" (A CAMPANHA..., 1942, p. 8) e em agosto o "Jornal dos Sports" (CAMPANHA..., 1942, p. 6) noticiava a entrega à CBD, pelo clube de São Januário, da quantia de um conto e oitocentos e vinte e quatro mil réis subscrita junto aos seus associados.

A bem-sucedida campanha do "Pax" levaria a diretoria do CRVG a propor nova subscrição aos seus associados e torcedores para a aquisição de mais uma aeronave a ser doada à FAB, dessa vez por iniciativa exclusiva do clube. Assim, em 10 de dezembro de 1942, o "Jornal dos Sports" anunciava, em sua primeira página, sob a chamada “Asas para Defesa dos Céus do Brasil!", que naquele dia seria entregue à FAB o avião de treinamento "Almirante Vasco da Gama", destinado ao Aeroclube da Bahia. Realizada no Estádio de São Januário, antes do jogo entre cariocas e paulistas pelo Campeonato Brasileiro de Seleções, a cerimônia foi presidida pelo ministro Salgado Filho, titular da recém-criada pasta da Aeronáutica (ASAS..., 1942, p. 1).

Além disso, entre 1942 e 1945, o CRVG organizaria diversas conferências cívicas; cederia seu estádio para eventos e jogos de futebol - como o "jogo de despedida" da FEB, entre Brasil e Uruguai, em 14 de maio de 1944; participaria da venda dos bônus de guerra e de diversas campanhas de arrecadação de recursos, como as lideradas por Delminda Aranha, esposa do ministro Oswaldo Aranha, que presidia o Comitê de Auxílio às Vítimas de Atentados do Eixo; intensificaria o

\footnotetext{
19 Entidade criada em 1914 para organizar e gerir não somente o futebol, mas todos os esportes olímpicos no Brasil. Foi reestruturada em 1979, em atendimento às exigências da FIFA, determinando que as Federações Nacionais dedicadas ao futebol fossem voltadas exclusivamente para esse esporte, originando a atual CBF (Confederação Brasileira de Futebol).
} 
apoio à Escola de Instrução Militar 307, mantida pelo clube em suas instalações desde o início dos anos 1930; e cederia as instalações de São Januário para alojar tropas da FEB oriundas de outros estados, antes do embarque para a Europa. Alinhados ao espírito da propaganda governamental sobre o esforço de guerra e sobre a atuação dos soldados brasileiros na Itália, também eram comuns nos "Boletins de Informações aos Associados", editados pelo clube, referências a sócios e atletas que estavam na Força Expedicionária, com a publicação, inclusive, de trechos de correspondências por eles enviadas do front (CRVG, 1960).

\section{b) Fluminense Football Club}

Em 1952, por ocasião do cinquentenário do Fluminense Football Club, Paulo Coelho Netto publicaria a sua "História do Fluminense"20, obra que obteria certa repercussão, não somente entre torcedores do clube. Procurando construir uma memória que enfatizasse o civismo como um elemento importante da identidade tricolor (FERNANDEZ, 2010, p. 169), Coelho Netto dedicou várias páginas do livro à participação da agremiação no esforço de guerra. Ao se transformar, nas décadas seguintes, em uma obra de referência para os pesquisadores do futebol carioca e também em fonte de consulta para a imprensa esportiva, ela contribuiu sobremaneira para que a atuação do tradicional clube de Laranjeiras durante os anos da Segunda Guerra Mundial se tornasse a mais conhecida, dentre os quatro grandes clubes cariocas.

De origem e tradições aristocráticas, o Fluminense F.C. teria papel central no processo de implantação do futebol profissional no Brasil e nas transformações no campo esportivo que aconteceriam na Era Vargas. A necessidade de montar equipes mais competitivas, a preocupação com o êxodo de jogadores para o exterior e as disputas entre grupos políticos distintos pelo controle do cada vez mais rendoso negócio do futebol levariam o clube - sob a liderança de Arnaldo Guinle, ex-presidente do Fluminense, da CBD e da AMEA

\footnotetext{
${ }^{20}$ Em 1969, o escritor publicaria um segundo tomo do livro, atualizando a história do clube até o ano de 1968. Em 2002, por ocasião do centenário do Fluminense, seria lançada nova edição da obra, compilando os dois tomos escritos por Paulo Coelho Netto e incluindo uma terceira parte, escrita por Rodrigo Nascimento, contemplando o período de 1969 a 2002
} 
(Associação Metropolitana de Esportes Athleticos) ${ }^{21}$ - a abandonar sua tradicional defesa do amadorismo e ficar à frente do grupo de clubes e entidades que defendia o profissionalismo no esporte.

Seria essa disputa entre "amadorismo" e "profissionalismo" - traduzindo "a luta pela hegemonia no controle do esporte entre duas elites que caracterizavam as tensões existentes no regime de Getúlio Vargas" (DRUMOND, 2009, p. 401) - que forneceria o pretexto para a já citada intervenção do Estado no campo esportivo:

No início da década de 1930, o apoio da sociedade ao projeto de intervenção do Estado no meio esportivo era mínimo. A oficialização era vista como uma medida prejudicial ao desenvolvimento esportivo, levando ao fracasso uma iniciativa que estava progredindo de forma privada e autônoma desde o final do século XIX. Na verdade, foram conflitos no interior do campo esportivo que possibilitaram ao Estado o consenso necessário na sociedade brasileira para empreender o seu projeto. (SOUZA, 2008, p. 39)

Além dessas questões, para o Fluminense, a profissionalização do futebol e a consequente separação entre o quadro social e os atletas profissionais (e, portanto, empregados) ajudariam a reforçar o caráter de distinção (e o recorte de classes) prezado pelo clube:

O profissionalismo, na verdade, resolvia uma questão que há muita preocupava uma parte dos sócios do Fluminense: a da inconveniente convivência com sócios de origens sociais mais baixas. Com a separação física dos espaços esportivos entre amadores e profissionais, cada qual em seu lugar, o clube mantinha a diferenciação que caracterizava amadores e profissionais. Os profissionais receberiam seus salários, serviriam ao clube e pronto. (FERNANDEZ, 2010, p. 148)

Esse contexto de disputas políticas pelo controle do campo esportivo em que um dos polos se aglutinava em torno de Arnaldo Guinle ${ }^{22}$ - e de

\footnotetext{
${ }^{21}$ A AMEA foi uma associação fundada em 1924 para organizar e administrar diversas modalidades esportivas do Rio de Janeiro, dentre elas o Futebol, e congregava os principais clubes cariocas. A entidade duraria até 1935, quando foi extinta durante o processo de reestruturação do futebol carioca, no bojo da disputa entre os defensores do amadorismo e os do profissionalismo.

22 Para maiores detalhes sobre o chamado "dissídio esportivo", que oporia o grupo de Arnaldo Guinle ao do dirigente botafoguense Rivadávia Meyer e que envolveria também Luiz Aranha, irmão de Oswaldo Aranha e presidente da CBD entre 1936 e 1943, ver DRUMOND, 2006; SOUZA, 2008 e FERNANDEZ, 2010.
} 
intervencionismo estatal no desporto, bem como o culto ao civismo como elemento de distinção, ajudam a entender o precoce e relativamente intenso engajamento do Fluminense F.C. na mobilização em torno da participação brasileira na Segunda Guerra Mundial, ainda nos agitados meses que antecedem a entrada formal do Brasil no conflito. No início de 1942, por exemplo, o tricolor carioca já estava bastante envolvido com a campanha para a compra do "Pax", organizando eventos esportivos de diversas modalidades para a arrecadação de fundos, como a competição hípica ocorrida no Estádio das Laranjeiras, em janeiro daquele ano (UM ESPETÁCULO..., 1942, p. 8).

Posteriormente, o clube articularia outra campanha junto aos seus associados para a aquisição de mais um avião a ser doado à FAB, um Fairchild PT-19, que receberia o nome de "Coelho Netto", em homenagem ao escritor Henrique Coelho Netto (1864-1934), destacado sócio e dirigente tricolor nas primeiras décadas do século XX. A aeronave de treinamento foi batizada em uma cerimônia no Estádio das Laranjeiras, antes de um jogo entre Flamengo e Fluminense - que ao terminar empatado em $1 \times 1$ daria o título estadual de 1942 para o tradicional rival -, e seria entregue ao Aeroclube de Campo Grande:

[...] Como sempre acontece, quando se defrontavam os dois grandes adversários, o estádio estava lotado. Terminada a prova preliminar, foi conduzido ao gramado, em frente à tribuna central das sociais, o avião "Coelho Netto", tendo a sua hélice ornada com o pavilhão tricolor e o motor encimado pela bandeira nacional. (COELHO NETTO, 2002, p. 152)

Nos meses seguintes, o clube continuaria organizando ou cedendo suas instalações para eventos relacionados ao esforço de guerra e ampliaria a atuação da Escola de Instrução Militar (a de número 185) que, a exemplo de outras agremiações esportivas, mantinha sua sede desde 1937, tendo sido incorporada à diretoria de recrutamento do Exército em 1938. Outra iniciativa da diretoria do clube seria a criação de uma escola de enfermagem, em junho de 1942, que começaria a funcionar em setembro daquele ano (COELHO NETTO, 2002).

No mesmo espírito que norteava a propaganda de guerra oficial, o clube estabeleceria, em setembro de 1942, a obrigatoriedade da leitura de um "Prefixo de Guerra” em todos os eventos esportivos por ele organizados, como era 
informado aos associados, em uma publicação interna de 1942, e também repercutido pela imprensa esportiva:

O Brasil está em guerra. Devemos sempre ter em mente a responsabilidade que cabe a cada um de nós na defesa da Pátria e na defesa do Continente. Cada brasileiro deve ser um soldado alerta, pronto para lutar pela nossa independência, por nossa cultura, pela nossa civilização. De pé, ao lado das grandes nações democráticas, estamos também lutando pela liberdade e pela justiça entre os povos, contra a opressão e a tirania do inimigo comum. Todas as nossas ações, todos os nossos pensamentos devem se orientar nessa hora grave, no sentido do esforço coletivo para a vitória. (PREFIXO..., 1942, p.4)

Assinado pelo então presidente do Fluminense, Marcos Carneiro de Mendonça - historiador, ex-atleta de futebol e primeiro goleiro da Seleção Brasileira, na década de 1910 -, o "Prefixo" enfatizava uma série de valores bastante caros à retórica do civismo tricolor - "defesa da pátria”, "da cultura", "da civilização", "luta contra a tirania" - e que, na construção da memória do clube por Paulo Coelho Netto, poucos anos depois, passariam a ser identificados como elementos centrais da sua identidade.

\section{c) Botafogo de Futebol e Regatas e Clube de Regatas do Flamengo}

José Perácio Berjun, ou simplesmente Perácio, foi um talentoso meiaatacante que chegou ao Botafogo F.C. em 1937, vindo do Villa Nova, de Minas Gerais. A rápida projeção obtida no clube carioca o levaria à Seleção Brasileira que disputou, com brilhantismo, a Copa do Mundo de 1938. Permanecendo na agremiação alvinegra até 1940, o jogador se transferiria para o C.R. Flamengo, em 1942, após rápida passagem pelo Canto do Rio, de Niterói, participando da vitoriosa equipe rubro-negra, tricampeã carioca entre 1942 e 1944. Nesse ano, o jogador foi convocado para a Força Expedicionária Brasileira e, apesar dos esforços da diretoria do Flamengo - inclusive com intercessões junto ao ministro da Guerra (e grande benemérito do clube), Eurico Gaspar Dutra -, Perácio acabaria embarcando para a Itália, onde serviu como motorista.

O meia-atacante do Flamengo foi um dos vários jogadores profissionais que participaram da Força Expedicionária Brasileira. Dos que atuavam em clubes 
cariocas, foram convocados para a guerra o meio-campista Geninho e o ponta esquerda Walter, do Botafogo, (CARVALHO; PEPE; MIRANDA, 1996), e o lateral Bidon, do Madureira E.C., além de diversos atletas amadores de diferentes esportes, inclusive do próprio futebol, como os botafoguenses Mato-Grosso e Dunga (idem). Além de terem sido, dentre os "quatro grandes", os únicos que tiveram jogadores de suas equipes profissionais lutando na Itália, Flamengo e Botafogo, como os seus rivais tricolores e cruzmaltinos, também se integrariam ao esforço de guerra.

Em 1942, o Brasil entrou na guerra, e também foi o ano em que seria criado o atual Botafogo de Futebol e Regatas, a partir da fusão do Botafogo Football Clube e do Clube de Regatas Botafogo, este último dedicado principalmente ao remo, ambos situados no bairro da zona sul da cidade que lhes emprestava o nome. A nova agremiação herdaria a tradição, os títulos esportivos, o patrimônio, os associados e os torcedores de seus antecessores.

Na década anterior, durante o "Dissídio Esportivo", o clube de futebol, sob a liderança de Rivadávia Corrêa Meyer, esteve à frente dos defensores da manutenção do amadorismo no futebol, assumindo posição diametralmente oposta a de seu mais antigo rival, o Fluminense F.C. Com dois de seus mais destacados dirigentes comandando a CBD nas décadas de 1930 e 1940 - Luiz Aranha (1936-1943) e o próprio Meyer (1943-1955) -, o clube teria participação ativa nos debates e disputas políticas que levaram à reconfiguração do futebol brasileiro no segundo quartel do século passado.

Assim, apesar da posição inicial do clube favorável ao amadorismo, foi durante o período de Aranha à frente da CBD que se consolidaria, por um lado, o maior controle do Estado sobre o desporto e, por outro, a adoção do profissionalismo como padrão para o futebol, padrão esse que, no entanto, não seria estendido a todos os esportes. Assim, "algumas modalidades permaneceriam amadoras, enquanto o futebol, devido à constituição efetiva de um mercado internacional reconhecido pela FIFA, passaria a ser essencialmente uma modalidade desportiva profissional” (SARMENTO, 2006, p. 58).

Com a criação do CND pelo decreto-lei no 3199/41, consolidando a centralização e o controle estatal sobre os esportes a partir da perspectiva de 
que eles "constituíam importante ferramenta de controle da sociedade e de promoção dos ideais de nacionalidade” (SARMENTO, 2006, p. 65), Aranha também assumiria a direção da nova entidade. Ao se afastar das duas, ele não deixaria de articular sua sucessão por nomes também ligados ao clube alvinegro: Meyer, na CBD, e João Lyra Filho, no CND.

Durante os anos do conflito mundial, além da participação de vários de seus atletas - profissionais e amadores - na FEB, o clube também se somaria ao esforço de guerra. Da mesma maneira que Vasco da Gama e Fluminense, o Botafogo F.R. se engajaria na Campanha Nacional de Aviação, organizada pelo Ministério da Aeronáutica e patrocinada pelos "Diários Associados”, arrecadando, junto aos seus sócios, recursos para a compra do monomotor "Paulo Goulart de Oliveira”, entregue à FAB em 1943 (AMADORES..., 1943, p. 4). O clube alvinegro também atuaria ativamente na divulgação e propaganda dos "Bônus de Guerra" e organizaria e participaria de cerimônias cívicas e de competições esportivas em prol dos combatentes da FEB (PARA..., 1944, p. 10) ou para arrecadar recursos para o "Fundo de Guerra".

O outro grande clube carioca, o Clube de Regatas do Flamengo, já era a mais popular dentre as principais equipes do Rio de Janeiro na primeira metade dos anos 1940. Tendo surgido como uma agremiação de elite - o departamento de esportes terrestres do clube (leia-se futebol), até então dedicado ao remo, seria criado em 1911, a partir de uma dissidência do Fluminense F.C. -, o Flamengo iria gradativamente se popularizar e ampliar exponencialmente a sua torcida, nas décadas seguintes. A mitologia rubro-negra consagra a história de que o clube, desde os seus primórdios, já teria um forte apelo popular, pois, por não possuir um estádio, treinava "na rua", atraindo pequenas multidões nesses treinamentos. Tal tese é de difícil sustentação empírica, sendo bastante complicado estabelecer qualquer relação entre o clube e as classes populares (e os seus valores) nos primeiros anos da sua história:

As matérias veiculadas na imprensa da época mostram como o Flamengo, assim como boa parte das instituições esportivas da Belle Époque, não tinha a menor pretensão de angariar simpatizantes nas camadas populares, e como seus eventos sociais eram altamente restritivos. (COUTINHO, 2013, p. 11) 
Deve-se lembrar também que, em 1924, no momento de criação da AMEA, - Flamengo estava entre os clubes que impuseram várias restrições à participação do Vasco da Gama na recém-criada entidade, todas elas relacionadas, implícita ou explicitamente, à origem social (e racial) de atletas do clube de São Januário (SANTOS, 2010).

Portanto, seria somente a partir do final dos anos 1920 e, principalmente, na década de 1930, que o processo de popularização do C.R. Flamengo ocorreria de fato. Uma das explicações para isso está relacionada à atuação da imprensa esportiva no período, notadamente a do “Jornal dos Sports" e de seu proprietário Mário Filho. Com o intuito de promover o recém-criado Campeonato Carioca de profissionais (e de vender jornais), Mário Filho - com o auxílio luxuoso de seu irmão Nelson Rodrigues, colunista de "O Globo" - foi o grande "inventor" da mística do "Fla x Flu", expressão por ele criada em 1933. A contratação, em 1936, de três populares jogadores negros pelo Flamengo - Leônidas da Silva, Domingos da Guia e Fausto dos Santos, todos com passagem pelo C.R. Vasco da Gama - e a simultânea opção tricolor por contratar um grande número de jogadores paulistas - brancos e vários com sobrenomes estrangeiros - daria o mote ideal para que o jornalista pudesse estabelecer a antítese entre o "time do povo" e o "time das elites" (FERNANDEZ, 2010).

No entanto, para além das estratégias midiáticas, o Flamengo também faria bem-sucedida passagem para o regime profissional, durante a gestão de José Bastos Padilha (1933-1937), o que se traduziu, inclusive, nas contratações mencionadas anteriormente. Nesse mesmo momento ocorreria também "um projeto de construção de novos símbolos identitários que permitiram reorganizar a relação da instituição com a torcida" (COUTINHO, 2013, p. 12), que possibilitaria a construção da imagem de "clube popular", em detrimento do passado elitista.

Esse processo aconteceria pari passu às transformações que ocorriam na sociedade brasileira naquela década, marcada pelo crescimento do proletariado urbano e pela incorporação das massas trabalhadoras à política, sob a égide do nacionalismo popular varguista. Como assinala Renato Coutinho, o clube rubronegro aderiria de forma entusiasmada a esse projeto, inclusive em seu viés mais autoritário, expresso na ditadura estadonovista: 
Atento a essas transformações sociais, o Flamengo foi o primeiro clube de futebol no Brasil que se apropriou do bem-sucedido discurso nacionalista estatal. Através de campanhas de marketing e ações sociais, o antes clube refinado passou a dialogar com os setores populares, reivindicando o posto de clube representante da nação. (COUTINHO, 2013, p. 13)

Um bom exemplo desta adesão é a parceria entre o Flamengo e a Cinédia para produzir, em 1937, um filme intitulado "Alma e Corpo de uma Raça”, que seria dirigido por Milton Rodrigues - irmão de Mário Filho e de Nelson Rodrigues. Tendo estreado nos últimos meses de 1938, a película, estrelada por atletas do clube, exaltava e romantizava valores extremamente caros ao Estado Novo:

O roteiro gira em torno de um love story, em que os valores do espírito desportivo e da eugenia da raça brasileira são constantemente trabalhados como pano de fundo. Apenas o título do filme já seria suficiente para deixar evidente sua identificação com o Governo Vargas, que chega cada vez mais próximo de seu apogeu. O filme entrou em cartaz nos últimos meses de 1938 e até mesmo o já ditador Getúlio Vargas compareceu ao Cinema São Luís para assistir à exibição da película. (DRUMOND, 2006, p. 110)

É nesse espírito - e sob os auspícios da sua reconfigurada identidade como clube popular - que se daria a participação do rubro-negro carioca na mobilização do front interno. Tendo no ministro da Guerra, general Eurico Gaspar Dutra, um torcedor ilustre e grande benemérito, o C.R. Flamengo organiza ou cede suas instalações para cerimônias cívicas, muitas delas contando com a presença de Dutra, o que incluía eventos em homenagem ao Exército (e ao próprio Dutra) e conferências proferidas pelo ministro (IMPONENTES..., 1943; O ESPORTE..., 1945). Também seriam realizados, em parceria com a Cruz Vermelha, cursos para a formação de enfermeiras socorristas e a criação de uma "hospitalização de emergência” na sede do clube, dirigida pelo superintendente do serviço médico rubro-negro, Newton Paes Barreto (COLABORA..., 1942; CURSO..., 1943).

No entanto, algumas das ideias sugeridas pela diretoria e por associados do clube acabaram não sendo implementadas, como - a exemplo do que fizeram outras agremiações cariocas -, a aquisição de um avião para a FAB ou, já em 1945, por ocasião do retorno dos Pracinhas, a construção de um "Arco do Triunfo" em homenagem à FEB. Para a consecução desta ambiciosa proposta, 
chegaram a ser feitas tratativas com o general Eurico Gaspar Dutra, com o ministro Salgado Filho e com Henrique Dodsworth, prefeito do Distrito Federal, que, no entanto, não foram em frente. As honras do C.R. Flamengo aos expedicionários acabariam sendo prestadas por vias indiretas e de forma mais modesta, através da iniciativa de um de seus beneméritos, Hilton Santos, também presidente da Confederação Brasileira de Esgrima: o dirigente esportivo articulou a confecção de distintivos com o desenho da cobra fumando, símbolo da FEB, que depois de vendidos pela Liga de Defesa Nacional para a arrecadação de fundos em prol dos expedicionários, foram remetidos para os soldados brasileiros no front por aqueles que os adquiriram (A COBRA..., 1944).

Assim, percebe-se que, embora variando de intensidade, as formas de inserção dos quatro grandes clubes cariocas no esforço de guerra são bastante similares: campanhas de arrecadação entre os sócios para a aquisição de aviões de treinamento e outros equipamentos para doação às Forças Armadas, venda de bônus de guerra, organização de eventos esportivos para arrecadação de fundos em prol dos expedicionários, cessão de suas instalações para atividades ligadas à mobilização para o conflito (formação de profissionais de saúde; alojamento de soldados; criação ou ampliação dos Tiros de Guerra, parte deles já instalados nos clubes desde antes do início da ॥ GM), realização de conferências e cerimônias cívicas. Todo esse engajamento não pode ser explicado somente pelo cumprimento do decreto que regulamentou os esportes nacionais e que previa a realização de atividades cívicas pelos clubes ou por outros tipos de pressão e coerção estatal.

No Rio de Janeiro, ao contrário de São Paulo, as principais agremiações sempre mantiveram relações amistosas e, muitas vezes, bastante próximas com o regime estadonovista. Na capital paulista, a fiscalização das autoridades governamentais - e mesmo a ameaça de cassação do registro - sobre clubes com grande número de sócios e diretores de origem estrangeira, como eram os casos do Palestra Itália / Palmeiras e do Corinthians (SALUN, 2007; STREAPCO, 2016), contribuíam para tensionar as relações entre os clubes e o Estado Novo. Ressalte-se que tais tensões começaram bem antes da guerra, remontando a 1938 e ao início das campanhas de nacionalização de comunidades estrangeiras, 
que atingiram diretamente o Palestra Itália / Palmeiras, símbolo clubístico da "italianidade" e cuja diretoria e principais patronos eram declarados simpatizantes/apoiadores do regime fascista italiano, tendo esse apoio se manifestado publicamente em episódios como a cessão do estádio do clube para comícios fascistas ou a recepção oferecida pelos dirigentes palestrinos ao filho de Mussolini (STREAPCO, 2016).

Questões similares não aconteceram com os clubes cariocas que, em maior ou menor grau, aderiram ao projeto varguista, contando, inclusive, com a presença de figuras próximas a Getúlio entre seus dirigentes, como era o caso dos irmãos Cyro (Vasco da Gama) e Luiz Aranha (Botafogo) ou mesmo do ministro da Guerra, Eurico Gaspar Dutra, que se não era dirigente, era torcedor declarado e grande benemérito do Flamengo, mantendo uma relação estreita com a diretoria do clube rubro-negro. Há que se assinalar também a forte base popular que Getúlio construiria no Rio de Janeiro que, não por acaso, tornar-se-ia um dos principais polos do trabalhismo pós-1945. Em clubes de massa, como já eram Flamengo e Vasco, a identificação de seus torcedores com o discurso nacionalpopular de Vargas dava sentido à própria identidade clubística, diferentemente do que ocorria em São Paulo, onde além das já mencionadas tensões decorrentes das campanhas de nacionalização, ainda estavam presentes as feridas da derrota da Revolução Constitucionalista de 1932.

Logo, na mobilização para o esforço de guerra, essa proximidade/identificação dos clubes cariocas, suas diretorias e seus torcedores com o projeto varguista se manifestaria com certa intensidade.

\section{Considerações finais}

O campo esportivo não ficaria alheio às grandes transformações ocorridas na sociedade brasileira no segundo quartel do século passado. A percepção do apelo popular e do poder mobilizador do futebol, por parte das novas elites políticas alçadas ao poder pela Revolução de 1930, fez com que o esporte passasse a ser utilizado politicamente, de forma sistemática, pelo Estado e seus agentes, como se veria, já em 1932, com a participação de Getúlio Vargas nas comemorações da conquista da Copa Rio Branco pela Seleção Brasileira (FREIXO, 
2014). Nesse contexto, o crescente intervencionismo estatal no esporte nacional, consolidado após a implantação da ditadura estadonovista, colocaria as entidades e agremiações esportivas sob tutela e ampliaria as conexões existentes entre elas e o regime varguista.

Dessa forma, a atuação dos clubes cariocas no esforço de guerra poderia ser entendida somente como mais um processo resultante da ação do Estado e dos mecanismos de repressão, vigilância e propaganda por ele utilizados para mobilizar a sociedade no front interno. No entanto, mesmo que tal dimensão não possa ser desconsiderada, ela não dá conta do grau de adesão e de envolvimento das diretorias, associados e aficionados das agremiações esportivas do Rio de Janeiro nessa mobilização. Cabe registrar que, além dos "quatros grandes", inúmeras outras agremiações esportivas se somariam ao esforço de guerra, como o América Football Club - o "quinto grande", o São Cristóvão de Futebol e Regatas ou o Bangu Atlético Clube.

Nessa visada, tal processo deve ser entendido como uma via de mão dupla: se por um lado existiram, de fato, pressões decorrentes da ação estatal sobre o esporte, por outro, não se pode negar a adesão entusiástica dos clubes e de suas diretorias ao esforço de guerra. Isso ocorreu por motivos vários, que iam da identificação com o projeto nacionalista popular do varguismo à associação entre a participação no esforço de guerra e o ethos clubístico, passando pela gama de interesses políticos ligados às disputas da época, no campo esportivo e fora dele, ou pelas especificidades e vinculações políticas de uma numerosa e influente colônia de imigrantes no Rio de Janeiro.

Ressalte-se, porém, que a entusiasmada adesão ao esforço de guerra não significou, necessariamente, que os clubes tenham relegado a segundo plano, em "nome da pátria", os seus objetivos e interesses mais específicos e imediatos. Com a manutenção das competições esportivas no país, apesar da guerra, a busca pela conquista de títulos continuaria a ser, em última instância, o norte maior dessas agremiações. O esforço, frustrado, da diretoria do C.R. Flamengo em obter a liberação de Perácio da FEB ilustra bem a tensão entre os interesses dos clubes e a mobilização do front interno. Longe de ser iniciativa isolada, tal 
prática foi relativamente corriqueira no período. Aparentemente, pouco habitual era a não obtenção da dispensa:

[...] houve a liberação, depois de pedido da Federação Metropolitana de Futebol do Rio de Janeiro, dos jogadores Danilo Alvim, Heleno de Freitas, Luiz Pereira, Nier Leite, Tomaz Soares da Silva [Zizinho], Isaías da Costa e Alfredo dos Santos. O que nos impressiona é que, mesmo a 1a Divisão Expedicionária precisando ao máximo de soldados com preparo físico para adequar-se às necessidades impostas pelo modelo americano, nenhum desses soldados foi embarcado para a Itália. (FEREIRA JÚNIOR, 2007, p. 19)

Apesar dessa ressalva, a entrada dos clubes, como instituições, na articulação do front interno mobilizaria um grande número de associados e torcedores de todos os estratos sociais, tanto nos clubes de perfil mais elitizado - Fluminense e Botafogo -, quanto nos mais populares - Vasco da Gama e Flamengo. Logo, mesmo que a adesão da sociedade ao esforço da guerra, de modo geral, tenha sido limitada e pouco entusiasmada, também houve, por parte de alguns segmentos, uma participação mais ativa e com certo grau de autonomia nesse processo. Na cidade do Rio de Janeiro, onde o trabalhismo varguista se tornaria uma das principais forças políticas nas décadas seguintes, os clubes de futebol seriam os espaços onde a atuação da sociedade se fez sentir com mais intensidade, demonstrando de forma efetiva a capacidade de mobilização e o grau de inserção social daquele que já era, no início dos anos 1940, o esporte das multidões, por excelência.

\section{Referências}

A CAMPANHA da CBD pró-avião "Pax". O Globo, Rio de Janeiro, p. 8, 14 maio 1942.

A COBRA está fumando - A homenagem dos esportes ao soldado expedicionário. Correio da Manhã, Rio de Janeiro, p. 10, 1 dez. 1944.

AGOSTINO, Gilberto. Vencer ou morrer: futebol, geopolítica e identidade nacional. Rio de Janeiro: Mauad, 2002. 
ALVES, Vágner Camilo. O Brasil e a Segunda Guerra Mundial: história de um envolvimento forçado. Rio de Janeiro: Ed. PUC-Rio; São Paulo: Loyola, 2002.

ALVES, Vágner Camilo. Da Itália à Coréia: decisões sobre ir ou não à guerra. Rio de Janeiro: IUPERJ; Belo Horizonte: Ed. UFMG, 2007.

AMADORES do Botafogo e Escola de Aeronáutica. Jornal dos Sports, Rio de Janeiro, p. 4, 15 out. 1943.

A PRIMEIRA conferência cultural do Vasco da Gama. Jornal dos Sports, Rio de Janeiro, p. 6, 15 abr. 1942.

ASAS para Defesa dos Céus do Brasil! Jornal dos Sports, Rio de Janeiro, p. 1, 10 dez. 1942.

CAMPANHA em prol do avião "Pax". Jornal dos Sports, Rio de Janeiro, p. 6, 21 ago. 1942.

CANCELLI, Elizabeth. A leniência e Vargas: falas da história. Estudos Históricos, Rio de Janeiro, v. 33, n. 71, p. 448-468, set./dez. 2020.

CAPELATO, Maria Helena. Propaganda política e controle dos meios de comunicação. In: PANDOLFI, Dulce (org.). Repensando o Estado Novo. Rio de Janeiro: Editora da FGV, 1999. p. 167-178.

CARVALHO, Estevão Leitão de. A serviço do Brasil na Segunda Guerra Mundial. Rio de Janeiro: Editora A Noite, 1952.

CARVALHO, Ney Oscar R. de; PEPE, Braz Francisco W.; MIRANDA, Luiz Felipe C. de. Botafogo, o Glorioso: uma história em preto e branco. Rio de Janeiro: Edição do Autor, 1996.

COELHO NETTO, Paulo. História do Fluminense (1902-2002). Rio de Janeiro: Pluri, 2002.

COLABORA o Flamengo no esforço de guerra do Brasil. Jornal dos Sports, Rio de Janeiro, p. 3, 13 dez. 1942.

CONN, Stetson; FAIRCHILD, Byron. A estrutura de defesa do hemisfério ocidental. Rio de Janeiro: Biblioteca do Exército, 2000.

CORSI, Francisco Luiz. Estado Novo: política externa e projeto nacional. São Paulo: Editora UNESP, 2000. 
COUTINHO, Renato Soares. Um Flamengo grande, um Brasil maior: o Clube de Regatas do Flamengo e o imaginário político nacionalista popular (1933-1955). 2013. Tese (Doutorado em História) - Universidade Federal Fluminense, Niterói, 2013.

COUTO, André Alexandre G. A hora e a vez dos esportes: a criação do Jornal dos Sports e a consolidação da imprensa esportiva no Rio de Janeiro (19311950). 2011. Dissertação (Mestrado em História Social) - Faculdade de Formação de Professores, Universidade do Estado do Rio de Janeiro, São Gonçalo, 2011.

COUTO, Euclides de Freitas. Da ditadura à ditadura: uma história política do futebol brasileiro (1930-1978). Niterói: EDUFF, 2014.

CRVG. C.R. Vasco da Gama e a F.E.B. Rio de Janeiro: Sociedade Gráfica Vida Doméstica, 1960.

CURSO de enfermeira socorrista no C.R. Flamengo. Correio da Manhã, Rio de Janeiro, p. 3, 6 mai. 1943.

CYTRYNOWICZ, Roney. Guerra sem guerra: a mobilização e o cotidiano em São Paulo durante a Segunda Guerra Mundial. São Paulo: EDUSP, 2000.

DUARTE, Carlos Sérgio Sobral. A política externa brasileira de 1934 a 1942: diplomacia "pendular" ou hegemonia americana? Cadernos do IPRI, Brasília, n. 2, p. 17-27, 1989.

DRUMOND, Maurício. Os gramados do Catete: futebol e política na Era Vargas (1930-1945). In: SILVA, Francisco Carlos Teixeira; SANTOS, Ricardo Pinto.

Memória social dos esportes: futebol e política: a construção de uma identidade nacional. Rio de Janeiro: Mauad, 2006. p. 107-132.

DRUMOND, Maurício. Nações em jogo: esporte e propaganda política em Vargas e Perón. Rio de Janeiro: Apicuri, 2008.

DRUMOND, Maurício. Vargas, Perón e o esporte: propaganda política e a imagem da nação. Estudos Históricos, Rio de Janeiro, v. 22, n. 44, p. 398-421, jul./dez. 2009.

FERNANDES, Luís. O encontro de tradições: prefácio. In: REBELO, Aldo.

Palmeiras x Corinthians 1945: o jogo vermelho. São Paulo: Editora UNESP, 2010. p. 17-20.

FERNANDEZ, Renato Lanna. Fluminense Foot-Ball Club: a construção de uma identidade clubística no futebol carioca (1902-1933). 2010. Dissertação (Mestrado em História, Política e Bens Culturais) - Centro de Pesquisa e Documentação, Fundação Getúlio Vargas, Rio de Janeiro, 2010. 
FERRAZ, Francisco César Alves. A guerra que não acabou: a reintegração social dos veteranos da força expedicionária brasileira. Londrina: EDUEL, 2012.

FERRAZ, Francisco César Alves. Polêmicas Historiográficas sobre a participação da Força Expedicionária Brasileira na Segunda Guerra Mundial. In: SIMPÓsIO NACIONAL DE HISTÓRIA, 23., 2013, Natal. Anais [...]. Natal: ANPUH, 2013.

FERREIRA JÚNIOR, Alcemar Uma Visceral Rebeldia: clientelismo e isenções no recrutamento da Força Expedicionária Brasileira (1943-1944). In: SANTOS, Claudia R. Andrade dos et al. Estudos: volume II. Curitiba: Série Grupo de Pesquisa - LEPH, 2007.

FORTES, Alexandre; RIBEIRO, Felipe. Trabalhadores e Segunda Guerra Mundial: debates introdutórios para um dossiê. Revista Mundos do Trabalho, Florianópolis, v. 11, p. 1-17, 2019.

FREIXO, Adriano de. Futebol: o outro lado do jogo. São Paulo: Desatino, 2014.

HILL, Cristopher. The changing politics of foreign policy. Nova York: Palgrave MacMillan, 2002.

IMPONENTES as solenidades no Estádio da Gávea. Jornal dos Sports, Rio de Janeiro, p. 1-3, 13 out. 1943.

McCANN JR., Frank D. Aliança Brasil-Estados Unidos, 1937/1945. Rio de Janeiro: Biblioteca do Exército, 1995.

MENESES, Filipe Ribeiro de. Salazar: biografia definitiva. São Paulo: Leya, 2011.

MESPLÉ, Antônio de Moraes. A Política externa brasileira numa era de conflito pela hegemonia mundial (1935-1942). Cadernos do IPRI, Brasília, n. 2, p. 29-45, 1989.

MOURA, Gerson. Autonomia na dependência: a política externa brasileira de 1935 a 1942. Rio de Janeiro: Nova Fronteira, 1980.

O ESPORTE e o exército. Correio da Manhã, Rio de Janeiro, p. 5, 11 jan. 1945.

OLIVEIRA, Dennison de. Aliança Brasil-EUA: nova história do Brasil na Segunda Guerra Mundial. Curitiba: Juruá Editora, 2015.

PANDOLFI, Dulce Chaves; GRYNSZPAN, Mario. Da revolução de 30 ao golpe de 37: a depuração das elites. Revista de Sociologia e Política, Curitiba, n. 9, p. 7-23, 1997. 
PANSARDI, Marcos Vinícius. Reinterpretando o Brasil: da revolução burguesa à modernização conservadora. Curitiba: Juruá Editora, 2009.

PARA o Natal do expedicionário. Correio da Manhã, Rio de Janeiro, p.10, 13 dez. 1944.

PAULO, Heloísa. Aqui também é Portugal: a colônia portuguesa do Brasil e o salazarismo. Quarteto Editora: Coimbra, 2000.

PREFIXO de Guerra. Um juramento de fé na vitória da liberdade e da justiça. Jornal dos Sports, Rio de Janeiro, p. 4, 26 set. 1942.

RAHMEIER, Andrea Helena Petry. Relações diplomáticas e militares entre a Alemanha e o Brasil: da proximidade ao rompimento (1937-1942). 2009. Tese (Doutorado em História) - Pontifícia Universidade Católica do Rio Grande do Sul, Porto Alegre, 2009.

RIO DE JANEIRO (Cidade). Prefeitura Municipal. Correio da Manhã: Compromisso com a verdade. Rio de Janeiro: Imprensa Oficial, 2001. (Cadernos de Comunicação: Série Memória).

SALUN, Alfredo Oscar. Palestra Itália e Corinthians: quinta coluna ou tudo buona gente? 2007. Tese (Doutorado em História Social) - Universidade de São Paulo, São Paulo, 2007.

SANDER, Roberto. O Brasil na mira de Hitler: a história do afundamento de navios brasileiros pelos nazistas. Rio de Janeiro: Objetiva, 2007.

SANTOS, João Manuel C. Malaia. Revolução vascaína: a profissionalização do futebol e a inserção sócio-econômica de negros e portugueses na cidade do Rio de Janeiro (1915-1934). 2010. Tese (Doutorado em História Econômica) Universidade de São Paulo, São Paulo, 2010.

SARMENTO, Carlos Eduardo. A regra do jogo: uma história institucional da CBF. Rio de Janeiro: CPDOC-FGV, 2006.

SCHNAIDERMAN, Boris. Guerra em surdina. São Paulo: Brasiliense, 1995.

SEITENFUS, Ricardo. A entrada do Brasil na Segunda Guerra Mundial. Porto Alegre: EDIPUCRS, 2000.

SOUZA, Denaldo Alchorne de. O Brasil entra em campo!: construções e reconstruções da identidade nacional (1930-1947). São Paulo: Annablume, 2008. 
STREAPCO, João Paulo França. Cego é aquele que só vê a bola: o futebol paulistano e a formação de Corinthians, Palmeiras e São Paulo. São Paulo: Edusp, 2016.

UM ESPETÁCULO de gala e sensação, esta noite, nas Laranjeiras. O Globo, Rio de Janeiro, p. 8, 20 jan. 1942.

VIGEVANI, Tullo. Questão nacional e política exterior: um estudo de caso: formulação da política internacional do Brasil e motivações da Força Expedicionária Brasileira. 1989. Tese (Doutorado em História Social) Universidade de São Paulo, São Paulo 1989. 